\title{
External Debt and Economic Growth: A Dynamic Panel Study of Granger Causality in Developing Countries*
}

\author{
Biqiong ZHANG', Muhammad DAWOOD ${ }^{2}$, Ahmed AL-ASFOUR ${ }^{3}$
}

Received: August 01, 2020 Revised: October 11, 2020 Accepted: October 15, 2020

\begin{abstract}
This study investigates the causal relationship between public and private external debt and economic growth in developing countries. Our model includes 18 selected Asian developing and transition economies from 1995 thru 2019. We employ the dynamic heterogeneous panel data methods, pooled mean group (PMG), robust cross-sectional augmented autoregressive distributed lag (CS-ARDL), and pairwise panel causality test. The results of PMG and CS-ARDL show the existence of causality between external debt and economic growth both in the short-run and long-run. The pairwise Granger causality test found the bidirectional causal relationship runs from total external debt, public external debt, and private external debt to economic growth and economic growth to external debt. The results showed first the existence of causality in the short-run and long-run between external debt and economic growth and the second, bi-directional causality that runs from external debt to economic growth and economic growth to external debt. Both the dynamic models and robust estimator found the same inferences about the impact of main variables on economic growth in Asian developing and transition economies. The findings of this study suggest to assure debt management, investment in productive sectors, increase domestic savings, decrease external dependency, and focus on international trade.
\end{abstract}

Keywords: External Debt, Economic Growth, Asia, Granger Causality, Pooled Mean Group

JEL Classification Code: F34, H63, G51, N15, P45

\section{Introduction}

The theoretical and empirical studies on the existence and direction of causality between external debt and economic

*Acknowledgements:

[1] We thank Mr. Abbas Shah, PhD Scholar, School of Economics, Zhongnan University of Economics and Law, Wuhan China and the editor of this journal for their constructive comments on first draft of this paper.

[2] There is no conflict of interest among the authors

${ }^{1}$ First Author. Professor, Department of International Finance, Central University of Finance and Economics Beijing, China.

Email: zhbq@cufe.edu.cn

${ }^{2}$ Corresponding Author. PhD Candidate, School of Finance, Central University of Finance and Economics Beijing, China [Postal Address: Mengzu Village, Baishan Town, Changping District, Beijing, 102206, China] Email: davidasri@gmail.com

${ }^{3}$ Director of the Center for Workforce Development, Associate Professor, Workforce Education and Development Program, School of Education, Southern Illinois University Carbondale, USA.

Email: Ahmed.alasfour@siu.edu

(c) Copyright: The Author(s)

This is an Open Access article distributed under the terms of the Creative Commons Attribution Non-Commercial License (https://creativecommons.org/licenses/by-nc/4.0/) which permits unrestricted non-commercial use, distribution, and reproduction in any medium, provided the original work is properly cited. growth have been debated for many decades. Developing countries have failed to bridge the gap between savings and investment, revenue, and expenditure due to a lack of capital or mismanagement of domestic resources. Low economic growth, high unemployment, poverty, inequality are the major problems in developing countries. The external debt financing is considered one of the significant sources to balance the twin deficits and dual gaps for economic growth (Senadza, Fiagbe \& Quartey, 2018; Ncanywa \& Masoga, 2018; Joy \& Panda, 2019; Ngo \& Nguyen, 2020a). Before the 1970s, the role of external debt was not harmful and not a problem until the 1980s. Before the 1970s, developing countries borrowed a relatively small amount of external funds from foreign governments, IMF, World Bank, and regional development banks. In that period, the interest rates were low at concessional terms, and resources of inflows were mostly bilateral grants and multilateral aids (Soydan \& Bedir, 2015). However, after the 1970s, the oil crisis started, and commercial banks started lending, then high accumulated debt and debt servicing burden became significant factors influencing economies. From this turning point forward, developing countries began to face many global macroeconomic challenges and imbalances 
in international markets such as losing adjustment in the exchange rate and failure in competitiveness in international trade, mismanagement of available resources, political unsustainability, and bad governance. The consequences of a high debt burden on developing countries become a persistent detriment. Increases in interest rates, resisting foreign inflows, lower domestic output, smaller earnings from exports, and an inability to import modern technological instruments resulted in economic growth slowing down (Riffat \& Munir, 2015).

Several studies examined the relationship and the impact of external debt on economic growth to make rational policies for sustainable development and economic growth for developing countries. Existing theoretical and empirical literature gives an ambiguous finding of external debt and economic growth nexus and answers the following questions; does external debt (public external debt, private external debt) cause an increase or decrease in economic growth? Is there a causal relationship or not? Is there bidirectional or unidirectional causality? Previous thoughts about external debt and economic growth causality stemmed from Reinhart and Rogoff's (2010) finding that external debt is a symptom, not a cause, of slowing the economic growth in developing countries. Krugman (1988) stated that external debt caused a decline in economic growth. For detailed views about external debt and growth nexus, see (Panizza \& Presbitero, 2014; Khursheed \& Siddiqui 2016; Chaudhry et al., 2017; Vita et al., 2018; Joy \& Panda, 2019; Patricia \& Ugwuanyi, 2019). Several econometric techniques are applied on different datasets and find the existence of causality as well as the direction of causality based on the assumption of crosssectional independence (see, Gomez-Puig \& Sosvilla-Rivero, 2015; Favour et al., 2017; Qureshi \& Liaqat, 2020; Akdugan \& Yild1z, 2020; Hameed \& Quddus, 2020). The findings of the above studies are diversified and contradicted regarding the impact, the existence of causality, and the direction of the causality between external debt's categories and economic growth. Thus, this can suggest that there is still room for the empirical investigation to allowing the cross-sectional dependence in developing countries to find the theoretical and empirical existence of causal relationship and direction of causality from external debts to economic growth. We are therefore motivated to address the following questions: Is there the existence of a causal relationship between external debt (total, public and private) and economic growth in Asian developing? What kind of causal direction runs from external debt to economic growth and economic growth to external debt in Asian developing?

The main objective of this study is to investigate the causal relationship between external debt (total external debt, public external debt, and private external debt) and the economic growth in developing over the period 1995 to 2019. This study is different from previous studies in several ways; Frist, to our knowledge, there is no study conducted on Asian developing countries. This study is performed on the Asian developing countries and contributes to the empirical literature on external debt and economic growth. Second, we used the macroeconomic panel data technique, such as the panel unit root and cointegration method, a relatively new approach. Third, we used the pooled mean group (PMG) and cross-sectional augmented autoregressive distributed lag (CS-ARDL) method to find the direction of causality between external debt and economic growth.

Apart from induction, this paper contains four main sections; the section presents a review of the theoretical and empirical literature. The third section is about the research methodology, econometric strategy, and sources of data. The fourth section presents empirical results and discussions and concludes the overall study with some policy recommendations in section five.

\section{Literature Review}

Theoretical, economic growth and development are the main goals of nations to reduce poverty and improve the quality of life of citizens (Ngo \& Nguyen, 2020b). A country has to accumulate many internal and external resources to achieve those macro goals. External debt financing is one of those external resources that affect economic growth such as foreign aid, FDI and exports. External debt affects economic growth negatively, which is mentioned by neoclassical and endogenous growth models (Aizenman et al., 2007; Diamond, 1965). Chaudhry et al. (2017) and Vita et al. (2018) highlighted five channels through which debt affect economic growth negatively, such as the Krugman's (1988) debt overhang hypothesis, Moss and Chiang's (2003) liquidity constraint hypothesis, Hansen's (2004) crowding out effect, Cochrane's (2011) uncertainty effect, and Tanzi and Chalk's, (2000) long-term interest rate. The positive channels, which support the famous Dual-Gap theory or "financing gap" where external financing is a prominent way to fill the gap of savings-investment or import-export gap, especially in developing countries. The channel through which external debt affects economic growth positively are productive projects, improvement in technology \& expertise, resource management, and a favorable balance of payment (Onuora, 2019). The Keynesians' school of thought believes that indebtedness does not charge either for present nor future generations because of its increasing demand and investment features, which are the result of increasing production. In contrast, the classical school of thought considered indebtedness as future tax and adverse effects on present and future generations because it hinders consumption and capital accumulation (Diallo, 2009). External debt helps to bridge the saving-investment gap, and foreign exchange as Hausmann and Panizza (2003) explained, that external debt 
is a helping tool for economic growth. The Debt Laffer Curve theory is a famous theory in economics that hypothesizes a nonlinear relationship between debt and growth on the assumption that there is an optimal level of debt that under this level, debt promotes growth and beyond that threshold, further debt accumulation impedes growth. See for more detail about the threshold effect of external debt (Panizza \& Presbitero, 2014; Eberhardt \& Presbitero, 2015; Chudik et al., 2013, 2017).

On empirical side some studies have found no causal relationship between debt and economic growth (Jilenga et al., 2016). Similarly, Ogunmuyiwa (2011) examined external debt and economic growth nexus from 1970 to 2007 for the developing country of Nigeria. He found that there is no causality between external debt and economic growth as Panizza and Presbitero (2014) found no evidence of causality from public debt to economic growth. Saungweme and Odhiambo (2020) also did not find causality from pubic debt to economic growth in the short and long terms. Musibau et al. (2018) investigated a causal relationship between external debt and economic growth in the Economic Community of West African States (ECOWAS) member countries from 1980 thru 2015 based on the debt overhang theory. The panel study results showed the existence of causality in the shortrun as well as in the long-run between external debt and economic growth. Jayaraman and Lau (2009) examined the relationship between public debt and economic growth to test causality in six Pacific island countries for the period 1985 to 2004. The results failed to investigate the long-run Granger causality relationship for both directions from real output to external debt/GDP ratio and from external debt to output in the short-run. Khursheed and Siddiqui (2016) examined the causality between external debt and economic growth in the short and long term in the South Asian economy from 1994 to 2014 by using multiple regression analysis techniques to find the causality from external debt to economic growth and found a positive linear relationship and causality in the short term as well as in the long-term.

Di-Sanzo and Bella (2015) examined the debt and growth relationship in 12-euro areas from 1970 to 2012 to test the causality for linear parametric and nonlinear nonparametric. They found mixed results such that unidirectional causality runs from debt to growth for Portugal and Spain and bidirectional causality for Belgium, Germany, Greece, Ireland, and Italy, while no causality for Austria, Finland, Luxembourg, and the Netherlands, see more studies (Korkmaz, 2015; Sultana Uddin et al., 2020). Favour et al. (2017) analyzed the impact of external debt on economic growth in Nigeria and found the existence of unidirectional causality runs from external debt to GDP, see other study with same findings (Ndubuisi, 2017). Saungweme and Odhiambo (2020) explored the short-run unidirectional causality from economic growth to public debt only in South Africa from
1970 to 2017, see another study in South Asian (Joshua et al., 2020) and in Sub Sahara African countries (Shittu et al., 2018).

Ferreira (2016) investigated the causality relationship between economic growth and three kinds of debt; public debt, foreign debt, and private debt in 28 sample countries of European Union for the two balanced panel data from 2001 to 2012 and from 2007 to 2012 to consider the outbreak of the global financial crisis of 2007 to 2008. Using panel Granger Causality estimations, the author found statistically relevant bidirectional causality runs from debt to economic growth and economic growth to debt and found clear evidence that economic growth decreases the public debt. See other supporting studies of bidirectional causality (Vita et al., 2018; Chaudhry et al., 2017; Bell et al., 2015). Butts (2009) examined the causal relationship between external debt and economic growth in the short term for 27 Latin American Caribbean countries from 1970 through 2003. In 13 countries of the sample, it was found that the causality runs from economic growth to short-term external debt, even has found a bidirectional causal relationship between external debt and economic growth (Abdelkafi, 2018; Ncanywa \& Masoga, 2018). Moreover, the causality relationship between debt and economic growth are supporting the negative causality runs from debt to economic growth (Chudik \& Pesaran, 2013; Shittu et al., 2018; Ciftcioglu \& Sokhanvar, 2018). Pattillo et al. (2004) examined the causality effect running from external debt to economic growth. They found negative and significant causality runs from external debt to economic growth. In contrast (Umaru et al., 2010) found positive bi-directional causation between external debt and economic growth in the case of Nigeria. After reviewing the theoretical and empirical literature of Granger causality about external debt and economic growth nexus, we found controversies in researchers' findings. Most studies focused on time series as well as panel data studies but were examined in advanced countries. The past studies used conventional methods, estimators, and tests to uncover the debt-growth relationship. Using the CS-ARDL estimator and Dumitrescu and Hurlin panel causality test this study addresses the literature gap in the case of developing countries to find the existence and direction of causality considering the cross-sectional dependence (CSD) problem in dynamic panel study of 18 Asian developing and transition economies from 1995 thru 2019.

\section{Data, Methodology, and Model Specification}

This study is based on the balanced panel dataset of the sample of 18 Asian developing countries for the period 1995 to 2019. The sample selection criterion is based on the availability of data for the main variables of the study. The 
study variables includes real GDP per capita, total external debt, public external debt, and private external debt. The data is collected from the EIU (Economic Intelligence Unit) country data. Annual real gross domestic product per capita (RGDPPC) in USD dollars as a proxy for economic growth, is used as a dependent variable (Yit). The main independent variables are total external debt, public external debt, and private external debt. Total external debt per head in USD in $\log (\mathrm{DTPH})$ is used as a proxy for total external debt public external debt to GDP (\%) - PEDS is the proxy for public external debt and private external debt to GDP (\%) -PRED is a proxy for private external debt.

\subsection{Methodology}

\subsubsection{Cross-sectional Dependence}

Cross-sectional dependence occurs among the countries and regional economies due to consideration of open economies, globalization, international trade openness, financial crisis, and omitted common factors (Chudik \& Pesaran, 2015). Cross-sectional dependence is a critical diagnostic issue in panel data, so it is essential to understand its extent and nature. Ignoring cross-sectional dependence in panel data analysis causes serious consequences (Shahbaz et al., 2017). It is critical to examine the presence of crosssectional dependence before testing unit roots, cointegrations, and estimations (Hasan, 2019).

\subsubsection{Stationarity}

The stationarity of the variables in this empirical analysis is done after cross-sectional dependence tests following (Menegaki, 2019). All the first-generation unit root tests are based on the assumption of cross-sectional independence. This study includes three first-generation unit root tests assuming cross-sectional independence, namely Levin -LinChu (2002)-LLC, Im-Pesaran-Shin (2003)-IPS, and Fishertype Duicky-Fuller (Choi 2001)-FDF following (Edo et al., 2020) as well as second-generation unit root test of Pesaran's (Cross-Sectional Augmented Dickey-Fuller -CADF) to count cross-sectional dependence, see in detail (Sharif \& Hamzah, 2015).

\subsubsection{Cointegration Tests}

This study applied the Pedroni (1999) cointergraton test which assumes the cross-sectional independence and the Westerlund (2007) cointegration test which considers the cross-sectional dependence to ascertain the presence of cointegration between the variables in the long-term following (Menegaki, 2019).

\subsubsection{Dynamic Panel Model : M.G, DFE, PMG, and Hausman test}

Based on secondary unit root tests, the autoregressive distributed lag (ARDL) model is suitable in case of mixed 1 $(0)$ and 1 (1) stationarity. There are three different estimations in the ARDL version to find the long and short-term effects of external debt on economic growth; the pooled mean group (PMG), mean group (M.G.), and the dynamic fixed effect (DFE) estimators. Guan and Lau (2018) suggested the PMG estimator for panel data in case of $\mathrm{T}$ relatively large and of the same order of magnitude as $\mathrm{N}$, the number of groups and mentioned its advantages. Instead of many advantages, PMG fails to adjust the heterogeneity and cross-sectional dependence, which produces insistent estimations. The general form of the PMG

$$
\boldsymbol{Y}_{i t}=\sum_{j=1}^{p} \lambda_{\mathrm{i}, \mathrm{j}} \boldsymbol{y}_{i, t-j}+\sum_{j=1}^{q} \delta_{i, j} \boldsymbol{x}_{i, t-j}+\mu_{t}+\varepsilon_{i t}
$$

The error correction equation can be derived from the above equation.

$$
\begin{aligned}
\Delta y_{i t}=\theta_{i}\left(y_{i, t-1}-\lambda_{i}^{\prime} X_{i, t}\right) & +\sum_{j=1}^{p-1} \lambda_{\mathrm{i}, \mathrm{j}} \Delta y_{i, t+j} \\
& +\sum_{j=0}^{q-1} \delta_{\mathrm{i}, \mathrm{j}} \Delta X_{i, t-j}+\mu_{t}+\varepsilon_{i t}(2)
\end{aligned}
$$

The parameter $\theta_{i}$ is the error-correcting speed of adjustment term, which must be negative and significant to have convergence in the long-run equilibrium. If $\boldsymbol{\theta}_{\boldsymbol{i}}=0$, then there would be no evidence for a long-run relationship. This parameter is expected to be significantly negative under the prior assumption that the variables show a return to long-run equilibrium. Of particular importance is the vector $\theta^{\prime}$, which contains the long-run relationships between the variables. The study applied all three estimators first to see whether there are significant differences among the PMG, M.G., and DFE and then applied the Hausman test to select the best estimator to find the long-run effect of external debt on economic growth and the existence of causality between external debt and economic growth. the ARDL lag structure is determined based on the Akaike information criterion (AIC). PMG is a more frequently used estimator as compared to M.G. and DFE, but it fails to account for the potential crosssection dependence issue. Therefore, this study employs the cross-sectionally augmented autoregressive distributed lag (CS-ARDL) model (Chudik \& Pesaran, 2015), which allows the cross-sectional dependence issue to be considered.

\subsubsection{Cross-Sectionally Augmented-ARDL (CS-ARDL)}

In the ARDL framework, an estimator was required to allow the heterogeneity and cross-sectional dependence 
in dynamic models to obtain the long-run and short-run coefficients. Chudik and Pesaran (2015) created an estimator; namely, cross-sectionally augmented autoregressive distributed lag (CS-ARDL), which accounts for the crosssectional dependence (Eberhardt and Presbitero, 2015). The previous studies of debt and growth were based on simple ARDL and found the Granger causality with the assumption of cross-sectional independence (Vita et al., 2018). This study attempted to find the existence of Granger causality between the external debts categories and economic growth by using the CS-ARDL estimator to find robust empirical findings.

\subsubsection{The Direction of Granger Causality}

Dumitrescu and Hurlin (2012) panel causality test is a pairwise Granger causality, which identified the direction of causality between the main variables of this study. This test has excellent sample properties and cross-sectional dependence resilient with the use of the bootstrap procedure to compute the $p$-values and critical values associated with the z-bare and z-bar tilde. In the pairwise Granger causality test, two variables are usually tested together to find the direction of causality with an expectation of either these results; bidirectional causality, unidirectional causality, and no causality. Granger causality is computed by running bivariate regressions in a panel data, which takes the following equation.

$$
y_{i t}=a_{i}+\sum_{k=1}^{K} \gamma_{k} y_{t-k}+\sum_{k=1}^{K} \beta_{i k} x_{i, t-k}+\varepsilon_{i, t}
$$

With $\mathrm{i}=1 \ldots \mathrm{N}$ and $\mathrm{t}=1 \ldots \mathrm{T}, \boldsymbol{x}_{\boldsymbol{i}, \boldsymbol{t}-\boldsymbol{k}}$, and $\boldsymbol{y}_{i t}$ are the observations of two stationary variables for individual i in period t. Coefficients can differ across individuals (note the i subscripts attached to coefficients) but are assumed to be time-invariant. The lag order $\mathrm{K}$ is assumed to be identical for all individuals, and the panel must be balanced.

\subsection{Model Specification}

First considered the standard panel ARDL approach and PMG estimator equations as following

$$
\begin{aligned}
\lg R G D P P C_{i t}= & \sum_{j=1}^{p} \lambda_{\mathrm{i}, \mathrm{j}} \lg R G D P P C_{i, t-j} \\
& +\sum_{j=1}^{q} \delta_{\mathrm{i}, \mathrm{j}} x_{i, t-j}+\mu_{t}+\varepsilon_{i t}
\end{aligned}
$$

The PMG estimator equation with error correction term can be derived from the previous equation

$$
\begin{aligned}
\Delta \lg R G D P P C_{i t}= & \theta_{i}\left(\lg R G D P P C_{i, t-1}-\lambda_{i}^{\prime} X_{i, t}\right) \\
& +\sum_{j=1}^{p-1} \lambda_{\mathrm{i}, \mathrm{j}} \Delta \lg R G D P P C_{i, t+j} \\
& +\sum_{j=0}^{q-1} \delta_{\mathrm{i}, \mathrm{j}} \Delta X_{i, t-j}+\mu_{t}+\varepsilon_{i t}
\end{aligned}
$$

Where: ECT: $\left(\lg R G D P P C_{i, t-1}-\lambda_{i}^{\prime} X_{i, t}\right)$ the error correction term; $\theta_{i}$ group-specific speed of adjustment coefficient; $X$ vector of independents variables; total external debt per head (DTPH), public external debt (PEDS), and private external debt (PRED) $\lambda_{i}^{\prime}$; the vector of long-run relationship; $\lambda_{\mathrm{i}, \mathrm{j}}, \delta_{\mathrm{i}, \mathrm{j}}$, is the short-run dynamic coefficients. $\mathrm{p}$ and $\mathrm{q}$ ranging from 1 to 3 for all variables.

This section, based on the stationarity tests and Hausman test, the ARDL model and PMG estimator as suitable estimators, respectively. Linking economic growth (RGDPP) to the explanatory variables of total external debt per head (DTPH), public external debt (PEDS), and private external debt $(P R E D)$ shows the existence of Granger causality between external debt categories and economic growth in 18 selected Asian developing and transition economies from 1995 thru 2019. The other two M.G and DFE estimators are applied to compare the results with the appropriate estimator of the study. After that, CS-ARDL as robust estimator to capture cross-sectional dependence to find the long-run effect and existence of the causality relationship of external debt categories and economic growth.

$$
\begin{aligned}
\Delta \lg R G D P P C_{i, t} & =a_{i}+\sum_{l=1}^{P y} \lambda_{1, i} \Delta \lg R G D P P C_{i, t-1} \\
& +\sum_{l=0}^{P x} \beta_{l, i} X_{i, t-1}+\sum_{l=0}^{3} Y_{i, l}^{\prime} \bar{z}_{t-1} \varepsilon_{i, t}
\end{aligned}
$$

$\bar{z}_{t-1}=\left(\bar{y}_{i, t-l}, \bar{x}_{i, t-l}\right) y_{\mathrm{i}, \mathrm{t}}$ is the log of real GDP per capita and $X_{\mathrm{i}, \mathrm{t}-1}$ are the main explanatory variables DTPH in log form, PEDS, and PRED defined above. The pairwise panel causality test equation of (Dumiterescu \& Hurlin, 2012) in our study runs from external debt categories to economic growth and economic growth to external debt categories. So, in total, there are six equations to show the direction of Granger causality.

$$
\begin{aligned}
& \lg R G D P P C_{i t}=a_{i}+\sum_{k=1}^{K} \gamma_{k} \lg R G D P P C_{t-k} \\
& +\sum_{k=1}^{K} \beta_{i k} D T P H_{i, t-k}+\varepsilon_{i, t} \\
& D T P H_{i t}=a_{i}+\sum_{k=1}^{K} \gamma_{k} D T P H_{t-k} \\
& +\sum_{k=1}^{K} \beta_{i k} \lg R G D P P C_{i, t-k}+\varepsilon_{i, t} \\
& \lg R G D P P C_{i t}=a_{i}+\sum_{k=1}^{K} \gamma_{k} \lg R G D P P C_{t-k} \\
& +\sum_{k=1}^{K} \beta_{i k} P E D S_{i, t-k}+\varepsilon_{i, t} \\
& P E D S_{i t}=a_{i}+\sum_{k=1}^{K} \gamma_{k} P E D S_{t-k} \\
& +\sum_{k=1}^{K} \beta_{i k} \lg R G D P P C_{i, t-k}+\varepsilon_{i, t}
\end{aligned}
$$




$$
\begin{aligned}
\operatorname{lgRGDPPC} C_{i t}= & a_{i}+\sum_{k=1}^{K} \gamma_{k} \operatorname{lgRGDPPC} C_{t-k} \\
& +\sum_{k=1}^{K} \beta_{i k} \operatorname{PRED}_{i, t-k}+\varepsilon_{i, t} \\
\text { PRED }_{i t}= & a_{i}+\sum_{k=1}^{K} \gamma_{k} \operatorname{PRED}_{t-k} \\
& +\sum_{k=1}^{K} \beta_{i k} \operatorname{lgRGDPPC_{i,t-k}}+\varepsilon_{i, t}
\end{aligned}
$$

\section{Results and Discussions}

\subsection{Summary of Descriptive Statistics}

Table 1 reports descriptive statistics of variables; real gross domestic product per capita as the dependent variable, representing the economic growth of the panel countries. Three main variables of external debt are total external debt (or total external debt per head, an alternate of total external debt), public external debt, and private external debt. The dependent variable and independent variables corresponding to their total observations, mean, standard deviation, minimum and maximum values are presented.

\subsection{Cross-Sectional Dependence}

Table 2 shows the results of the pre-estimation crosssectional dependence test of Breusch-Pagan LM of the variables. The finding of four cross-sectional dependence test results provides that all the variables are significant at $1 \%$, which rejected the null hypothesis of cross-sectional independence. The alternative hypothesis is accepted and confirmed the existence of cross-sectional dependence among Asian developing countries. The null hypothesis of cross-sectional independence is rejected and identified that cross-sectional dependence exists in all variables.

\subsection{Stationarity}

Table 3 shows the first-generation and second-generation unit roots tests; LLC, IPF, and FDF. The first generation of tests assumes that cross-section units are cross-sectionally independent whereas the second generation of panel unit root tests reclines this assumption and allows for cross-sectional dependence. According to second-generation unit root tests, the real GDP per capita (RGDPPC), the dependent variable, is non-stationary with a trend aspect, while stationary only at lag ' 1 ' without a trend aspect. The first-generation tests, LLC and FDF also showed that the dependent variable is non-stationary at level $1(0)$. DTPH is stationary at the level by second-generation against the first-generation. PEDS is non-stationary by second-generation and stationary, according to the first generation. PRED is stationary at the level showed by second-generation in contrast to firstgeneration. So, overall, the results showed that the order of integration is not the same, and no variable is stationary on the second difference. Out of nine variables, five variables are stationary at level with trends, and four variables are non-stationary. According to the first-generation unit root tests, RGDPPC, DTPH, PEDS, PRED are non-stationary, but secondary generation tests showed only the PEDS is non-stationary. The second-generation unit root test with optimal three (3) lags are applied. Specification with and without trend, the Pesaran (2007) CIPS unit root results lead to apply the estimators which handle the stationary and nonstationary variables in the case of CSD. Both unit root tests showed no variable stationery at the second difference I (2), which is valid to apply the ARDL approach.

Table 1: Summary of descriptive statistics

\begin{tabular}{|l|c|c|c|c|c|}
\hline Variable & Obs & Mean & Std. Dev. & Min & Max \\
\hline Real GDP per capita & 450 & 6399.975 & 8155.716 & 367.0085 & 39122.59 \\
\hline Total external debt per head & 450 & 1999.514 & 2550.66 & 17.1 & 12347 \\
\hline Public External debt & 450 & 21.27402 & 19.31865 & .0023144 & 93.70501 \\
\hline Private External Debt & 450 & 21.17352 & 32.25707 & .1191733 & 194.6852 \\
\hline
\end{tabular}

Table 2: Cross-Sectional Dependence tests

\begin{tabular}{|l|c|c|c|c|}
\hline Tests & RGDPPC & DTPH & PEDS & PRED \\
\hline Breusch-Pagan LM & $2920.818^{* * *}$ & $388.4576^{* * *}$ & $925.3803^{* * *}$ & $1105.088^{* * *}$ \\
\hline Pesaran scaled LM & $158.2256^{* * *}$ & $13.46021^{* * *}$ & $44.15404^{* * *}$ & $54.42722^{* * *}$ \\
\hline Bias-corrected scaled LM & $157.8506^{\star * *}$ & $13.08521^{* * *}$ & $43.77904^{* * *}$ & $54.05222^{* * *}$ \\
\hline Pesaran CD & $52.73910^{* * *}$ & $11.47777^{* * *}$ & $5.926995^{* * *}$ & $15.13952^{* * *}$ \\
\hline
\end{tabular}


Table 3: 1st and 2nd Generation Panel Unit Root Tests

\begin{tabular}{|c|c|c|c|c|c|c|c|c|c|c|}
\hline \multicolumn{4}{|c|}{$\begin{array}{l}\text { 1st Generation Panel Unit Root Tests } \\
\text { (Ho: variable is non-stationary } 1(I))\end{array}$} & \multicolumn{7}{|c|}{$\begin{array}{l}\text { (B) Pesaran (2007) } 2^{\text {nd }} \text { Generation Panel Unit Root test (CIPS) } \\
\text { (Ho: variable is stationary at } 1(\mathrm{I}))\end{array}$} \\
\hline \multirow{2}{*}{ Variables } & \multicolumn{3}{|c|}{ At level $1(0)$ and first difference1(I) } & \multirow{2}{*}{$\begin{array}{l}\text { lag } \\
\mathbf{s}\end{array}$} & \multicolumn{3}{|c|}{ Specification without trend } & \multicolumn{3}{|c|}{ Specification with trend } \\
\hline & LLC & IPS & FDF & & Zt-bar & p-value & t-bar & Zt-bar & p-value & t-bar \\
\hline $\begin{array}{l}\text { RGDPPC } \\
(\log )\end{array}$ & $\begin{array}{c}0.13361 \\
(0) \\
-3.7815^{\star * *} \\
1(I)\end{array}$ & $\begin{array}{c}7.5974 \\
1(0) \\
-7.1377^{\star * *} \\
1(\mathrm{I})\end{array}$ & $\begin{array}{c}-2.9431 \\
1(0) \\
25.5185^{\star * *} \\
1(\mathrm{I})\end{array}$ & $\begin{array}{l}0 \\
1 \\
2 \\
3\end{array}$ & $\begin{array}{c}1.410 \\
-1.568 \\
-1.264 \\
1.533 \\
\end{array}$ & ** & $\begin{array}{l}-1.428 \\
-2.108 \\
-2.039 \\
-1.400 \\
\end{array}$ & $\begin{array}{c}2.756 \\
0.426 \\
-1.404 \\
0.988\end{array}$ & & $\begin{array}{l}-1.706 \\
-2.217 \\
-2.618 \\
-2.093\end{array}$ \\
\hline DTPH(log) & $\begin{array}{c}1.9152 \\
1(0) \\
-4.7748^{\star \star *} \\
1(\mathrm{I})\end{array}$ & $\begin{array}{c}7.7029 \\
1(0) \\
-7.8953^{\star \star \star} \\
1(\mathrm{I})\end{array}$ & $\begin{array}{c}-2.9403 \\
1(0) \\
21.4109^{\star \star *} \\
1(I)\end{array}$ & $\begin{array}{l}0 \\
1 \\
2 \\
3\end{array}$ & $\begin{array}{l}-0.751 \\
-1.937 \\
-2.535 \\
-2.300\end{array}$ & $\begin{array}{l}* * \\
* * * \\
* *\end{array}$ & $\begin{array}{l}-1.922 \\
-2.193 \\
-2.330 \\
-2.276\end{array}$ & $\begin{array}{l}0.709 \\
-0.056 \\
-0.633 \\
-1.943\end{array}$ & ** & $\begin{array}{l}-2.155 \\
-2.322 \\
-2.449 \\
-2.736\end{array}$ \\
\hline PEDS & $\begin{array}{c}0.2475 \\
1(0) \\
-6.9272^{* * *} \\
1(I)\end{array}$ & $\begin{array}{c}2.6228 \\
1(0) \\
-8.1669^{\star \star \star} \\
1(\mathrm{I})\end{array}$ & $\begin{array}{c}-1.5442 \\
1(0) \\
26.5970^{* * *} \\
1(I)\end{array}$ & $\begin{array}{l}0 \\
1 \\
2 \\
3\end{array}$ & $\begin{array}{c}0.340 \\
-0.076 \\
-0.130 \\
-0.991\end{array}$ & & $\begin{array}{l}-1.672 \\
-1.767 \\
-1.780 \\
-1.977\end{array}$ & $\begin{array}{l}2.970 \\
2.388 \\
3.125 \\
2.535\end{array}$ & & $\begin{array}{l}-1.659 \\
-1.787 \\
-1.625 \\
-1.754\end{array}$ \\
\hline PRED & $\begin{array}{c}-0.7000 \\
1(0) \\
-4.0708^{* * *} \\
1(\mathrm{I})\end{array}$ & $\begin{array}{c}1.9656 \\
1(0) \\
8.8163^{* * *} \\
1(\mathrm{I})\end{array}$ & $\begin{array}{c}-1.6920 \\
1(0) \\
30.6679^{* * *} \\
1(I)\end{array}$ & $\begin{array}{l}0 \\
1 \\
2 \\
3\end{array}$ & $\begin{array}{l}-1.044 \\
-2.001 \\
-2.522 \\
-0.342\end{array}$ & $\stackrel{* *}{* * *}$ & $\begin{array}{l}-1.989 \\
-2.207 \\
-2.327 \\
-1.828\end{array}$ & $\begin{array}{l}-1.001 \\
-1.463 \\
-3.285 \\
-0.824\end{array}$ & $\stackrel{*}{*}$ & $\begin{array}{l}-2.529 \\
-2.631 \\
-3.030 \\
-2.491\end{array}$ \\
\hline
\end{tabular}

Table 4: Cointegration tests

\begin{tabular}{|c|c|c|c|c|c|c|c|}
\hline \multirow{2}{*}{$\begin{array}{l}\text { Ho: No cointegration } \\
\text { Tests }\end{array}$} & \multicolumn{2}{|c|}{$\begin{array}{c}\text { Pedroni cointegration } \\
\text { test }\end{array}$} & \multicolumn{5}{|c|}{ Westerlund Cointegration test Ho: No } \\
\hline & Statistic & p-value & Statistic & Value & Z-value & P-value & $\begin{array}{l}\text { Robust } \\
\text { P-value }\end{array}$ \\
\hline Modified variance ratio & -3.7789 & 0.0001 & Gt & -1.913 & 3.851 & 1.000 & 0.000 \\
\hline Modified Phillips-Perront & 0.7317 & 0.2322 & $\mathrm{Ga}$ & -4.745 & 5.693 & 1.000 & 0.000 \\
\hline Phillips-Perront & -0.9929 & 0.1604 & $\mathrm{Pt}$ & -4.468 & 6.357 & 1.000 & 0.000 \\
\hline Augmented Dickey-Fullert & -0.6762 & 0.2495 & $\mathrm{~Pa}$ & -3.191 & 5.001 & 1.000 & 0.000 \\
\hline
\end{tabular}

\subsection{Cointegration Analysis}

Table 4 reports two types of cointegration tests of Pedroni and Westerlund to show the existence of cointegration among the interested variables. The results of Pedroni cointegration tests are not valid in case of cross-sectional dependence, so the Westerlund cointegration test is used as alternative test to consider the cross-sectional dependence. The results shows the existence of causality between variables. For the robust check of the existence of Granger causality, the dynamic panel models are estimated as strong evidence in the next section.

\subsection{Dynamic Models and Existence of Causality: MG, DFE, PMG-ARDL and CS-ARDL}

Based on the above preliminaries of cross-sectional dependence tests, stationarity test, and cointegration test, this study applied first all three estimators to see whether there are significant differences among the PMG, M.G, and DFE and then applied the Hausman test to select the best estimator to find the long-run effect of external debt on economic growth and existence of causality between external debt and economic growth in Table 5. For comparison purposes, the study estimated the M.G. and DFE as well to show the short-run and long relationship between the external debt and economic growth. According to the results of M.G. and DFE, there is a short-run relationship between all external debts variables and economic growth. There is no long-run relationship that exists in M.G, but DEF shows the long-run relationship for DTPH and PEDS only. PMG is an often used estimator to show the long-run effect as compared to M.G. and DFE, but it fails to account for the potential crosssection dependence issue. To avoid the incorrect inferences and inconsistent estimates, the cross-sectional autoregressive 
distributed lag estimator (CS-ARDL) is used to find the dynamic effects of debts on economic growth.

Table 5 below depicts the pool mean group ARDL estimator and cross-sectional autoregressive distributed lag (CS-ARDL) results of three main exploratory variables and the dependent variable. This study preferred the CS-ARDP estimator results due to the existence of crosssectional dependence. Based on the CS-ARDL estimator, the long-run and short-run causality existence are identified. Table 5 presented both of the estimator's results with the corresponding coefficient variables and probability values. CS-ARDL long-run and short-run results showed the association and causality between dependent and independent variables at the 0.01 significance level. When the DTPH $(\log )$ increases in one unit, the RGDPPC $(\log )$ increases by $9.75 \%$ in the long-run and $6.67 \%$ in the shortrun. The PEDS goes up in one unit; the RGDPPC decreases $0.30 \%$ in the long-run and $.23 \%$ in the short-run. There is $0.28 \%$ in the long-run and $0.20 \%$ in the short-run decrease in RGPPC due to one unit increase in PRED.

Overall the results of the CS-ARDL estimator showed the association between all the debt categories and economic growth, which reflexed the existence of causality. The PMG results in the long-run and short-run also the same without considering the cross-sectional dependence in the data. In the long-run and short-run, there is a positive relationship between DTPH and RGDDP. PEDS and PRED have a negative association with RGPPC in the short term as well as in the long-run, meaning that when the public and private long-term external debt are borrowed, the economic growth goes down. Comparatively, based on the PMG and CS-ARDL results, pubic external debt (PEDS) decreases the economic growth more than private external debt, as seen in the Table below. Causality in the sense that the additional external debt borrowing by public and private sectors of Asian developing countries causes to decrease in economic growth. Total external debt showed a positive association because it includes short term debt and IMF credits too, so it might be the increase in economic growth when the total external debt increase. Subsequently, from this study, it is learned that there are adverse effects of long-term external debt on economic growth in developing countries. The CS-ARDL estimator also showed the existence of causality (positive and negative) in dynamic panel data setup.

Table 5: M.G, DFE, PMG-ARDL and CS-ARDL

\begin{tabular}{|c|c|c|c|c|c|c|c|c|}
\hline Dependent Var & \multicolumn{2}{|c|}{ MG } & \multicolumn{2}{|c|}{ DFE } & \multicolumn{2}{|c|}{ PMG } & \multicolumn{2}{|c|}{ CS-ARDL } \\
\hline RGDPPC(log) & Long-run & Short-run & Long-run & Short-run & Long-run & Short-run & Long-run & Short-run \\
\hline DTPH (log) & 6.6109 & $.1313^{* * *}$ & $.5119^{* * *}$ & $.0662^{* * *}$ & $.9913^{* * *}$ & $.1544^{* * *}$ & $.0975^{* * *}$ & $.0667^{* * *}$ \\
\hline PEDS & .4376 & $-.0046^{* * *}$ & $-.0179^{*}$ & $-.0026^{* * *}$ & $-.0199^{* * *}$ & $-.0048^{* * *}$ & $-.0033^{* * *}$ & $-.0023^{* * *}$ \\
\hline PRED & -.2113 & $-.0025^{* * *}$ & -.0017 & $-.0003^{* *}$ & $-.0125^{* * *}$ & -.0030 ** & $-.0028^{* * *}$ & $-.0020^{* * *}$ \\
\hline Cons & & $.19848^{*}$ & & $.0667^{\star \star}$ & & $.0419^{* *}$ & & \\
\hline ECT & & $-.0835^{*}$ & & -.0224 & & $-.0286^{*}$ & & \\
\hline Hausman test: & \multicolumn{2}{|c|}{$\begin{array}{c}\text { MG vs PM chi2 }(3)= \\
5.34 \\
\text { Prob>chi2 }=0.15\end{array}$} & \multicolumn{2}{|c|}{$\begin{array}{l}\text { DFE vs PM chi2 }(3)= \\
0.00 \quad \text { Prob }>\text { chi } 2=0.10\end{array}$} & \multicolumn{2}{|c|}{$\begin{array}{l}\text { Decision: Prob>chi2 is } \\
\text { greater than } 0.05 \text { PMG } \\
\text { is the best estimator }\end{array}$} & \multicolumn{2}{|c|}{$\begin{array}{l}\text { CS-ARDL estimator is } \\
\text { the robust estimator to } \\
\text { account the CSD problem }\end{array}$} \\
\hline
\end{tabular}

${ }^{*} p<0.1{ }^{* *} p<0.05{ }^{* * *} p<0.01$ significance levels respectively

Table 6: Dumitrescu and Hurlin pairwise panel causality test

\begin{tabular}{|c|c|c|c|c|c|c|c|}
\hline Hypothesis & W-bar & Z-bare & p-value* & c.value & Z-bare tilde & $p$-value & c.value \\
\hline \multirow{2}{*}{$\begin{array}{l}\text { DTPH does not Granger- } \\
\text { cause RGDPPC(log) } \\
\text { RGDPPC(log) does not } \\
\text { Granger-cause DTPH }\end{array}$} & 2.8910 & 5.6730 & $0.0700^{*}$ & 6.2070 & 4.4687 & $0.0700^{*}$ & 4.9142 \\
\hline & 6.0096 & 15.0288 & $0.0070^{* * *}$ & 11.5615 & 12.2728 & $0.0070^{* * *}$ & 9.3806 \\
\hline \multirow{2}{*}{$\begin{array}{l}\text { PEDS does not Granger- } \\
\text { cause RGDPPC (log) } \\
\text { RGDPPC(log) does not } \\
\text { Granger-cause PEDS }\end{array}$} & 6.8552 & 10.2995 & $0.0030^{\star * *}$ & 6.1725 & 7.6583 & $0.0030^{* * *}$ & 4.4230 \\
\hline & 4.0174 & 9.0523 & $0.0530^{*}$ & 9.1798 & 7.2875 & $0.0530^{*}$ & 7.3939 \\
\hline \multirow{2}{*}{$\begin{array}{l}\text { PRED does not Granger- } \\
\text { cause RGDPPC(log) } \\
\text { RGDPPC(log) does not } \\
\text { Granger-cause PRED }\end{array}$} & 32.0081 & 31.8533 & $0.0020^{* \star *}$ & 13.7093 & 8.4014 & $0.0020^{* * *}$ & 2.9919 \\
\hline & 4.3522 & 10.0565 & $0.0400^{* *}$ & 9.2931 & 8.1252 & $0.0400^{* *}$ & 7.4884 \\
\hline
\end{tabular}

${ }^{*} p<0.1{ }^{* *} p<0.05^{* * *} p<0.01$ significance levels respectively, $c$-value; critical value 


\subsection{The Direction of Granger Causality}

Table 6 shows the test null hypothesis of no homogenous Granger causality against the alternative hypothesis indicating causality for at least one cross-sectional unit of the panel from total external debt to economic growth and from economic growth to external debt. The results show that the p-value rejected the null hypothesis 'DTPH does not Granger cause to RGDPPC' and 'RGDPPC does not Granger cause to TDPH at 0.10 and 0.01 level of significance respectively. The alternative hypothesis is external debt cause to economic growth, and economic growth cause to the external debt. So, there is bidirectional causality between total external debt and economic growth. The direction of Granger causality of public external debt with economic growth is hypothesized in the second number that PEDS does not Granger cause to RGDPPC, and RGDPPC does not granger cause to PEDS. The p-value rejected the null hypothesis and found the bidirectional Granger causality among the public external debt and economic growth at .01 and .05 significance. The last pairwise is private external debt and economic growth; the p-value rejected the null hypothesis and showed the bidirectional causality at .01 and .10 significance level. The direction of causality between private external debt and economic growth is also bidirectional causality because the p-value of the hypothesis is less than .05 level of significance in both directions.

\section{Conclusion}

This study examined the existence and direction of Granger causality between external debt economic growth in selected Asian developing and transition economies from 1995 thru 2019. The dynamic panel data methodologies of the pooled mean group -PMG and cross-sectional augmented autoregressive distributed lag CS-ARDL, as well as Dumitrescu and Hurlin panel causality test, are applied to find the existence and direction of causality between external debt and economic growth in developing countries. The results showed first the existence of causality in the short-run and long-run between external debt and economic growth and the second, bi-directional causality that runs from external debt (total external debt, public external debt, and private external debt) to economic growth and economic growth to external debt (total external debt, public external debt, and private external debt). Both the dynamic models and robust estimator found the same inferences about the impact of main variables; total external debt, public external debt, and private external debt on economic growth in Asian developing and transition economies. Based on the finding of the study, it is cleared that most developing countries face problems in making robust macroeconomic policies of monetary policy, fiscal policy, structural policies, and global corporations to solve the problems of financial instability, budget-deficits, and indebtedness. Developing countries can solve the indebtedness problems by controlling the additional external financing, investing in productive projects by the private sector, educating people toward saving behavior, debt management policies, political stability, and focus on foreign direct investment, international trade, and technology.

\section{References}

Abdelkafi, I. (2018). The relationship between public debt, economic growth, and monetary policy: Empirical evidence from Tunisia. Journal of Knowledge of Econometrics, 9(4), 1154-1167.

Akdugan, U., \& Y1ldı, N. (2020). The relationship between external debt and economic growth: the case of fragile five countries. Gümüşhane Üniversitesi Sosyal Bilimler Enstitüsü Elektronik Dergisi, 11(2), 448-460. Retrieved from https:// dergipark.org.tr/tr/pub/gumus/issue/55299/683615

Bell, A., Johnston, R., \& Jones, K. (2015). Stylised facts or situated messiness? The adverse effects of increasing debt on national economic growth. Journal of Economic Geography, 15(2), 449-472.

Butts, H. C. (2009). Short term external debt and economic growth-granger causality: Evidence from Latin America and the Caribbean. The Review of Black Political Economy, 36, 93111.

Chaudhry, I. S., Iffat, S., \& Farooq, F. (2017). Foreign direct investment, external debt and economic growth: Evidence from some selected developing countries. Review of Economics and Development Studies, 3(2), 111-124.

Chudik, A, \& Pesaran, M. H. (2015). Common Correlated Effects Estimation of Heterogeneous Dynamic Panel Data Models with Weakly Exogenous Regressors. Journal of Econometrics, 188(2), 393-420.

Chudik, A., \& Pesaran, M. H. (2013). Large panel data models with cross-sectional dependence: A survey. Globalization Institute Working Papers No. 153, Federal Reserve Bank of Dallas.

Chudik, A., Mohaddes, K., Pesaran, M. H., \& Raissi, M. (2017). Is there a debt-threshold effect on output growth? Review of Economics and Statistics, 99(1), 135-150.

Cochrane, J. H. (2011). Understanding policy in the great recession: some unpleasant fiscal arithmetic. European Economic Review, 55(1), 2-30

Diallo, B. (2009). External Debt and Financing of Economic Development in Guinea. National Directorate of Economic Studies and Forecasting, Ministry of Economy and Finance, Conakry-Republic of Guinea.

Di-Sanzo, S., \& Bella, M. (2015). Public debt and growth in the euro area: Evidence from parametric and nonparametric Granger causality. The B.E. Journal of Macroeconomics, 15(2), 631-648. 
Dumitrescu, E. I., \& Hurlin. C. (2012). Testing for Granger noncausality in heterogeneous panels. Economic Modelling, 29(4), $1450-1460$.

Eberhardt, M., \& Presbitero, A. (2015). Public debt and growth: Heterogeneity and non-linearity. Journal of International Economics, 97(1), 45-58.

Edo, S., Nneka, E. O., \& Isuwa, F. D. (2020). Growing external debt and declining export: The concurrent impediments in economic growth of Sub-Saharan African Countries. International Economics, 161, 173-187.

Favour, E. O., Idenyi, O. S, Oge, E. O., \& Charity, I. A. (2017). Public debt and economic growth in Nigeria. Asian Research Journal of Arts \& Social Sciences, 4(3), 1-16.

Ferreira, C. (2016). Debt and economic growth in the European Union: A panel granger causality approach. International Advances in Economic Research, 22(2), 131-149.

Gomez-Puig, M., \& Sosvilla-Rivero, S. (2015). The causal relationship between debt and growth in EMU countries. Journal of Policy Modelling, 37(6), 974-989

Guan, L. P., \& Lau, W. Y. (2018). Triffin Dilemma and International Monetary System: Evidence from Pooled Mean Group Estimation. Journal of Asian Finance, Economics and Business, 5(2), 5-14. http://doi.org/10.13106/jafeb.2018.vol5. no2.5

Hansen, H. (2004). The Impact of External Aid and External Debt on Growth and Investment. In: T. Addison, H. Hansen, \& F. Tarp, (Eds.). Debt Relief for Poor Countries (pp.134157). London, UK: Palgrave Macmillan. https://doi. org/10.1057/9780230522329_7

Hasan, M. A. (2019). Does globalization accelerate economic growth? South Asian experience using panel data. Journal of Economic Structures, 8(26). https://doi.org/10.1186/s40008019-0159-x

Hausmann, R., \& Panizza, U. (2003). On the determinants of original sin: an empirical investigation. Journal of International Money and Finance, 22(7), 957-990.

Jayaraman, T. K., \& Lau, P. H. (2009). Does external debt lead to economic growth in Pacific island countries? Journal of Policy Modelling, 31, 272-288.

Jilenga, M. T., Xu, H., \& Gondje-Dacka, I. M. (2016). The impact of external debt and foreign direct investment on economic growth: Empirical evidence from Tanzania. International Journal of Financial Research, 7(2), 154-162.

Joshua, U., Adedoyin, F. F., \& Sarkodie, S. A. (2020). Examining the external-factors-led growth hypothesis for the South African economy. Heliyon, 27, 10553-10564.

Joy, J., \& Panda, P. K. (2019). Pattern of External Debt and its Impact on Macroeconomic Variables in India. International Journal of Economic Research, 16(1), 261-272.

Khursheed, A., \& Siddiqui, F. (2016). Do debt boosts economic growth? a study of the South Asian countries. International Journal of African and Asian Studies, 22, 1-16.
Korkmaz, S. (2015). The relationship between external debt and economic growth in Turkey. Proceedings of the second European academic research Conference on Global Business, Economics, Finance and Banking, Zurich, Switzerland.

Krugman, P. (1988). Financing vs. Forgiving a Debt Overhang. Journal of Development Economics, 29(3), 253-68.

Menegaki, A. N. (2019). The ARDL Method in the Energy-Growth Nexus Field; Best Implementation Strategies. Economies, 7(4), 105. https://doi.org/10.3390/economies7040105

Moss, T. J., \& Chiang, H. S. (2003). The other costs of high debt in poor countries: growth, policy dynamics, and institutions. Debt Sustainability Issue Paper No. 3, Washington, DC: The World Bank Group.

Musibau, H. O., Mahmood, S., Ismail, S., Shamsuddin, Z., \& Rashid, N. (2018). Does external debt cause economic growth? An experience from ECOWAS Member Countries. International Journal of Academic Research in Business and Social Sciences, 8(11), 1256-1264.

Ncanywa, T., \& Masoga, M. M. (2018). Can public debt stimulate public investment and economic growth in South Africa? Cogent Economics \& Finance, 6, 1-13.

Ndubuisi, P. (2017). Analysis of the impact of external debt on economic growth in an emerging economy: Evidence from Nigeria. African Journal Review, 11(4), 156-173.

Ngo, M. N., \& Nguyen, L. D. (2020a). Economic Growth, Total Factor Productivity, and Institution Quality in Low-Middle Income Countries in Asia. Journal of Asian Finance, Economics and Business, 7(7), 251-260. https://doi.org/10.13106/ jafeb.2020.vol7.no7.251

Ngo, M. N., \& Nguyen, L. D. (2020b). The Role of Economics, Politics and Institutions on Budget Deficit in ASEAN Countries. Journal of Asian Finance, Economics and Business, 7(9), 251261. https://doi.org/10.13106/jafeb.2020.vol7.no9.251

Ogunmuyiwa, M. S. (2011). Does external debt promote economic growth in Nigeria? Current Research Journal of Economic Theory, 3(1), 29-35.

Onuora, O. G. (2019). Effect of external debt on the economic growth of developing countries. Online Journal of Arts, Management and social sciences, 4(1), 1-8.

Panizza, U., \& Presbitero, A. F. (2014). Public debt and economic growth: Is there is a causal effect. Journal of Macroeconomics, 41(C), 21-41.

Patricia, N. N., \& Ugwuanyi, W. (2019). Direct and reverse causation of external debt, foreign investment and economic growth in Nigeria, 1980-2017. South Asian Journal of Social Studies and Economics, 4(1), 1-12.

Pattillo, C., Poirson, H., \& Ricci, L. (2004). What are the channels through which external debt affects growth? African and Asia and Pacific departments. IMF Working Papers No. 04(15). Washington, DC: International Monetary Fund. 
Pedroni, P. (1999). Critical values for cointegration tests in heterogeneous panels with multiple regressors. Oxford Bulletin of Economics and Statistics, 61, 653-670.

Qureshia, I., \& Liaqatb. Z. (2020). The long-term consequences of external debt: Revisiting the evidence and inspecting the mechanism using panel VARs. Journal of Macroeconomics, 63, 103184 .

Reinhart, C. M., \& Rogoff. K. S. (2010). growth in a time of debt. NBER Working Papers No. 15639, Cambridge, MA: National Bureau of Economic Research.

Riffat, N., \& Munir, M. (2015). Exploring the channels and impact of debt on economic growth in South Asia. MPRA Paper No. 66830 .

Saungweme, T., \& Odhiambo, N. M. (2020). Causality between public debt, public debt service, and economic growth in an emerging economy. Studia Universitatis Babes-Bolyai Oeconomica, 65(1), 1-9.

Senadza, B., Fiagbe, A. K., \& Quartey, P. (2018). The effect of external debt on economic growth in Sub-Saharan Africa. International Journal of Business and Economic Sciences Applied Research, 11(1), 61-69.

Shahbaz, M., Sarwar, S., Chen, W., \& Muhammad, M. N. (2017). Dynamics of electricity consumption, oil price and economic growth: Global perspective. Energy Policy, 108, 256-270.
Shariff, N. S. M., \& Hamzah, N. A. (2015). A robust panel unit root test in the presence of cross-sectional dependence. Journal of Modern Applied Statistical Methods, 14(2), 159-171.

Shittu, W. O., Hassan, S., \& Nawaz, M. A. (2018). The nexus between external debt, corruption and economic growth: evidence from five SSA countries. African Journal of Economic and Management Studies, 9(3), 2040-0705.

Soydan, A., \& Bedir, S. (2015). External debt and economic growth: New evidence for an old debate. Journal of Business, Economics \& Finance, 4(3), 500-522.

Sultana, T., Uddin, S., Rahman, M. M., \& Faruk, O. (2020). External debt and Economic growth in Bangladesh: An Error Correction Approach. International Journal of Engineering Technology Research \& Management, 4(8).

Tanzi, V., \& Chalk, N. (2000). Impact of large public debt on growth in the EU: A discussion of potential channels. European Economics, 2, 23-43.

Umaru, A., Hamidu, A., \& Musa, S. (2013) External debt and domestic debt impact on the growth of the Nigerian economy. International Journal of Educational Research, 1(2), 70-85.

Vita, G. D., Trachanas, E., \& Luo, Y. (2018). Revisiting the bi-directional causality between debt and growth: Evidence from linear and nonlinear tests. Journal of International Money and Finance, 83, 55-74. 